\title{
Enhancing the Learning Outcomes of Civic Education through Online Module
}

\author{
Eko Prasetyo \\ Graduate School \\ Universitas Negeri Yogyakarta \\ Yogyakarta, Indonesia \\ 13705251026@student.uny.ac.id
}

\author{
Abdul Gafur Daniamiseno \\ Graduate School \\ Universitas Negeri Yogyakarta, \\ Yogyakarta, Indonesia \\ Abdul_gafur@uny.ac.id
}

\begin{abstract}
This current study aims at describing the development, eligibility, and effectivity of online module of civic education in junior high school. This investigation applies a Research and Development (R\&D) approach adapting Borg and Gall's model through a series stage, namely (1) initial study, covering potentials and problems, collecting information; (2) the preparation stage, including arranging product design, production, expert judgment, and content; (3) piloting, evaluating, and revision; and (4) implementation. The informants of this present study were obtained from teachers, students, and experts in civic education. The data were collected through test, observation, interview, and documentation. The result of this study is an online module for civic education of junior high school students in order to enhance their learning outcomes, material of independence in expressing opinion is presented in a form of module which is able to be accessed through internet, feature in the development of online module is in the form of a learning containing application containing application instruction, module instruction, preface, first, second, and third learning materials, tasks, case study, learning video, bibliography, and profile of module developer. The eligibility of the online module is considered high. It is proved by (a) expert validation (materials and media), (b) one by one piloting, (c) small group piloting with a high average score, and (d) field piloting with criteria (good). The implementation of the online module for senior high school students is effective to cultivate their learning outcomes with the score of $92.30 \%$.
\end{abstract}

Keywords- online module, civic education, learning outcomes

\section{INTRODUCTION}

A conventional-dominated civic education is potential to alienate students from their technologybased life. Students are exposed to only a lecture and indoctrination learning strategy. According to Soemantri, a civic education is still utilizing a traditional learning technique i.e. lecturing and indoctrination [8]. In the curriculum of elementary, junior and senior high school in 1968, critical and creative thinking, participation, and problem-solving had been acknowledged by the teachers in the process of civic learning. However, the traditional method was still applied. There were many factors rendering its implementation, such as the examination which is based on memorizing which leads to the exertion of the implementation of a problem-solving since the civic learning materials as contained in the curriculum 1968 for junior high school students were about national history (30\%) and statehood $(70 \%)$ and Pancasila and Constitution 1945 (100\%) for senior high school students.

Nowadays, the implementation of civic education cannot only be based on the method. Sumaidi stated that the students' life is indeed depending on the presence of communication and technology growing within people such as an internet, hand phone, twitter, Facebook and the like [7].

An effort to rationalize the civic learning correlating to student's life regarding their literacy of technology is mandatory to keep their decent reception or stigma. The teachers' literacy towards technology is also crucial to develop an interesting and effective class so that the students' learning motivation will increase impacting the cultivation of their learning outcomes. The rapid upsurge of education is undeniable marked by people's awareness to invest in the arena education. Through education, people are expected to be capable and skillful who independently convalesce their standard of living physically and psychologically as well as enhancing their role as an individual, community member, citizen, and His caliphate.

Indonesian Constitution Number 20 the year 2003 about national education system states the definition of education as follows.

"A conscious and planned effort to realize the learning atmosphere and process, therefore, the students are actively engaged in their selfpotential-development to acquire spiritual, selfcontrol, intelligence, noble morals as well as the skill required by themselves, and citizens [1].

The abovementioned definition can be interpreted that education means a sequence of activity institutionally (such as school or Islamic-based school) which is used to perfect an individual development in acquiring knowledge, habitual action, attitude, and so forth. An education can run formally in schools, Islamic-based schools, and many other institutions.

An education is closely related to teaching and cannot be separated. An education cannot be accomplished without a teaching, and the teaching itself cannot be directed without any purposes of education. Besides, an education is an effort to a 
holistic self-development and closely related to image and value. Furthermore, an education is an effort to an intellectual capacity building and many other physical skills. The process of education can be successful if it is supported by an attractive means of learning media, materials, students' competence, teachers' performance, learning climate, and learning system.

The old paradigm, which is affected by a mindset, at that time, is apprehended as an education organizer for maturing students. The assumption of the old education paradigm is as follow.

a) The educator transfers the knowledge easily by studying the abstract concept and, sometimes, the concept is not correlated with the context;

b) The students are the receivers of knowledge;

c) The learning is behavioristic and involves the fostering of stimulus-response;

d) The students are in the condition of 'empty' and are ready to be filled;

e) The skill and knowledge are better to be grasped separately from their context [2].

The new paradigm of the learning process transforms from teachers centered to students centered. The students act as the learning main actors, as well as the teacher act as the facilitator functioning as a trigger and ginger to the students to keep studying. Hence, the students will experience the process of the learning maximally. An alternative to the implementation of the education, through the development of the teaching-learning material, is that by cultivating a module. A module is a learning material which can be utilized independently by the students in order to achieve its brand-new paradigm and the foster of the students' learning outcomes. Therefore, the developed module is the online one considering the elevation of technology living within human beings.

Daryanto, stated that a module is one of the forms of a comprehensive and systematic learning material. It contains a series of a well-prepared learning experience and is designed to help the students to acquire their specific goals of learning [3]. Besides, a module has its strong enough information. The elements of association, structure, and steps of learning are set so that the students spontaneously can learn it. A module gives many opportunities to the students to be active so that it opens many other opportunities to be sustainable based on their own capabilities.

Directorate of Education stated that the use of the module is often correlated to a self-instruction activity [4]. Another consequence regarding this term that should be fulfilled is that the comprehensiveness of the content; meaning that the content and the presentation of the materials should completely be elaborated through the presentations so that the students are able to understand a certain subject they study in the module. However, if the readers (students) desire to the development of acquaintance regarding the subject, they are suggested to trace it through its bibliography attached at the end of the module. The content of the module should be comprehensive, neither the pattern of the presentation nor the content.

The appropriateness of the online module is observed based on an expert judgment of media and material, one-by-one piloting, small group piloting, as well as field piloting. According to Widiarni the standard of its success should meet at $75 \%$ of all students pursuing cognitive test, therefore, it is effective [5].

The literary studies regarding this study depict that the use of the module is effective to cultivate the students' learning outcomes. Wijanarka's study about the use of the module in vocational school proves its success to cultivate students' competence in dealing with the curriculum [6]. Suwasono and Putranto on their study of the implementation of the online module on a distance learning is proper and effective to be utilized as its learning sources [7]. Parmin and Peniati stated that the online learning in a natural science shows its appropriateness regarding the use of the module and it can enhance the learning outcomes as well [8].

Based on the studies, it is crucial to investigate a research under the title "The Development of Online Module of Civic Education for Junior High School to Enhance the Students Learning Outcomes". The niche of this current study is the online module for the students of Junior High School grade VII combining several interesting-attractive features such as animated pictures, tasks that can be answered directly as well as the students are able to see the result instantly. This module can easily be accessed using a computer, laptop, and hand phone having an internet access and flash program.

\section{RESEARCH METHOD}

This research is designed as a Research and Development (R\&D) utilizing a descriptive procedural model. The development of the module was started through the initial step to the generation of the online module of civic education for Junior High School in line with the cycles of R\&D proposed by Borg and Gall [9].

The research steps to accomplish covers (1) research and data collection, in this model, this is the so-called initial research; (2) planning; (3) developing initial product; (4) initial piloting; (5) revising main product; (6) main piloting; (7) revising operational product; (8) field piloting; (9) revising final product; and (10) dissemination and implementation.

Adapted from this model, the developments of this model were (1) initial study, covering potential and problem, collecting information; (2) planning: arranging product design, production, expert, and 
content; (3) piloting, evaluating and revising; and (4) implementation.

The objects of this present study were the experiment and control class in SMP N 22 Surakarta. This study involved several informants including teachers, students, headmasters, and civic education expert. The data for this current study were in the form of questionnaires, interviews, observation, and documentation. Those generated the online form of the module. The module was judged regarding the materials and the learning media in line with the quality of the module which had been developed based on the aspects of learning, materials, and media. The analyzed descriptive-qualitative data were in the form of comments, revise-suggestion, and the result of observation during the process of piloting and was concluded as a proposal to improve and revise the developed product. The data were in the form of a score and expert judgment of media, materials, and students obtained through questionnaires, and were analyzed throughout a descriptive-qualitative approach with percentage and categorization.

\section{RESULT AND DISCUSSION}

The development of online module of civic education in the senior high school under the theme "Freedom to Express an Opinion" can be accessed by the students through an internet. The features in the present development of the online module are in the form of instruction to the application, instruction module, preface, learning materials, tasks, case study, bibliography, learning video, and the creator's profile. The utilization of the online module can motivate the students to follow the learning process ending up with the cultivation of their outcomes significantly.

The configuration of the online module of the civic education is divided into several parts: title, materials, videos, and evaluation. The title consists of the title of media (Online Module of Civic Education). The title of the learning materials, the identity of the education stage, the identity of the writer, and the identity of the institution.

The appearance of the online module is completed with an animated picture supporting the presentation of the learning material. The purpose of the presence of the animated picture is to attract the student to get engaged in the learning. The look of competitive examination is designed for the students to get interacted and challenged in accomplishing the tasks. The students should answer the questions in every slide. The result is then depicted at the end of their accomplishment.

The façade of the video aims at assisting the students to comprehend the materials so that they do not only read the materials but watch the video regarding the materials as well. This can be picturized at the following picture below.

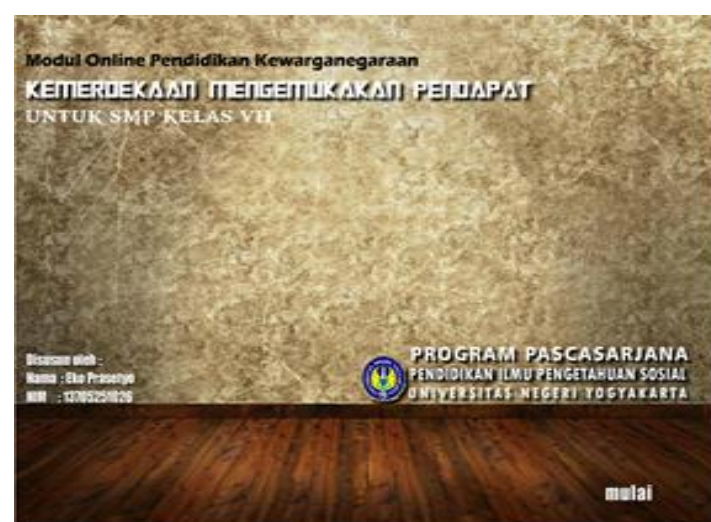

Fig. 1. The Appearance of the Title

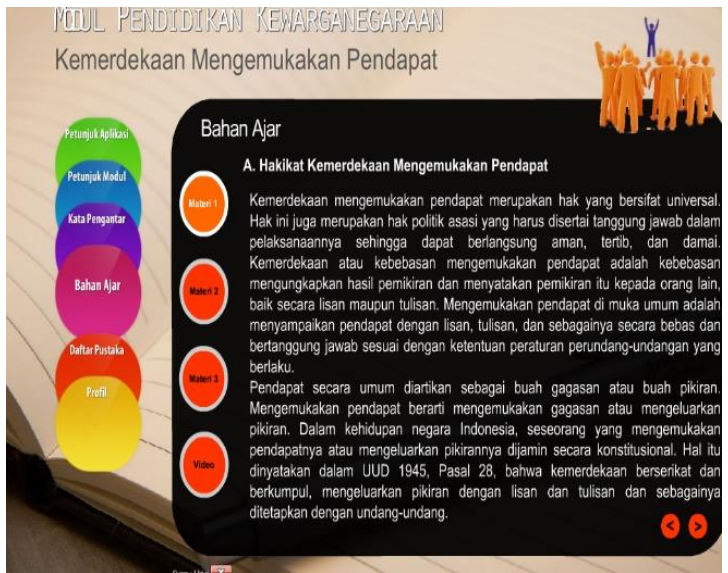

Fig. 2. The Appearance of Materials

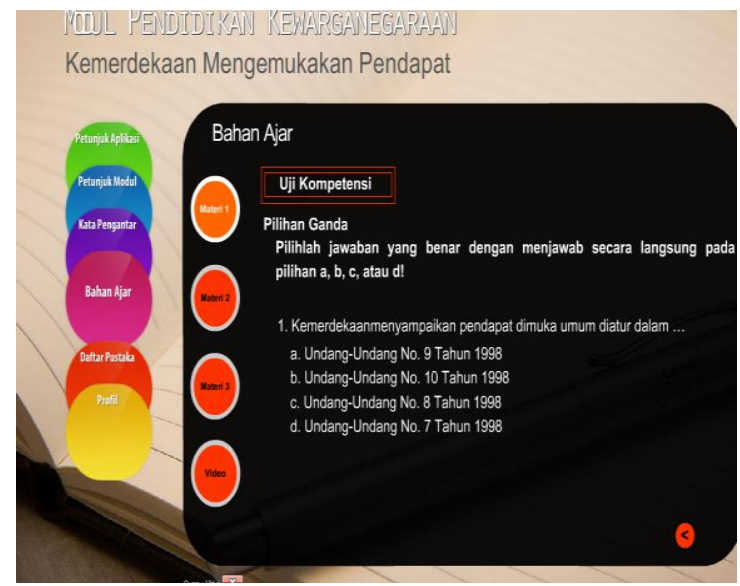

Fig. 3. The Appearance of Competence Examination

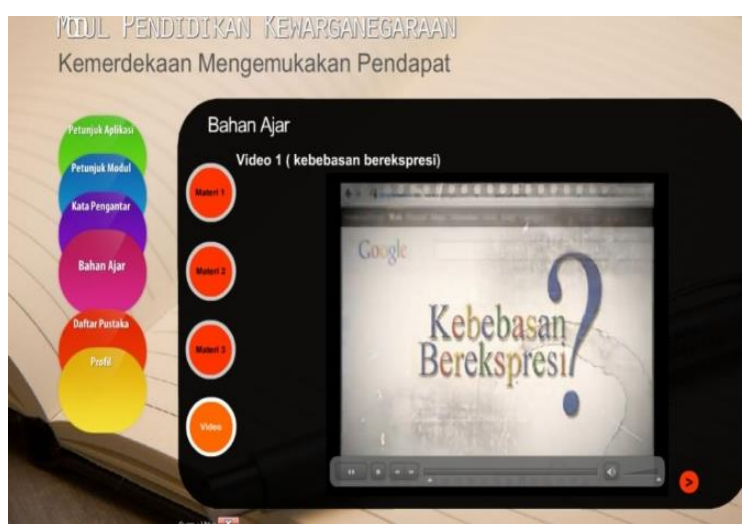

Fig. 4. The Appearance of Video 


\section{A. Data on Product Piloting from the First Stage of Evaluation}

The data were collected from the expert on material and media judgment. The data were validated by Dr. Mukhammad Murdiono, M.Pd. as a lecturer of Civic Education, Faculty of Social Science and Graduate Program, Universitas Negeri Yogyakarta. The reason why selecting him as the data validator is that of his competence regarding the civic education. the validation was accomplished in order to obtain the data which can be used as this study's reference to mend the presented material at the online module product developed in this study. The expert evaluation data were obtained from questionnaires consisting of 27 questions, where 16 questions were reviewed from the aspect of the learning, and 11 questions were reviewed based on the material aspects.

The data of the evaluation aspects attain an average score of 4.00 with a good criterion. Further, the based on the aspect of materials, the online module gets an average score of 3.81 with a good criterion.

In addition, the expert judgment was accomplished by Dr. Mukminan, M.Pd., a lecturer of Graduate Program at Universitas Negeri Yogyakarta. This is because of his expertise in the arena of media. The validation was done to obtain the data which will be utilized as the reference to cultivating the presented media on the online module developed in this study. The evaluation data were achieved through a questionnaire consisting of 9 questions reviewed from the aspect of the learning media and it gets an average score of 4.00 with a good criterion.

\section{B. Data on Product Piloting from the Second Stage of Evaluation}

The data from this stage were obtained through a one-to-one evaluation. This evaluation was done by five students of grade VII SMP Negeri 22 Surakarta. The selected students were considered as having different capabilities. A student has the higher competence, and two others have the lower one. Before the piloting was accomplished, the researcher explained the procedure to operate, then the students access the internet to download the online module. Next, the students fulfill the questionnaire provided. In this piloting, the students are requested to learn the materials from the online module of the civic education that had been revised. The students are asked to observe the display of the online module and based on their observation; they answered the questionnaire.

The learning evaluation data aspect on the piloting shows the average score 4.40 with a good criterion, and the range of the score "good" existed in the aspect of its appropriateness to the SK, the vividness of the indicator to the basic competence, the clarity of the product target, the lucidity of the learning materials, the balance of the materials to the series of the test questions, and ten other aspects that shows a "very good" criterion.

The material evaluation data on the one-to-one evaluation shows the average score 4.40 with a "very good" criterion, there are 4 good criteria on the aspect of the validity of the materials, sequence of the materials, systematic and contextual, and the ability to accommodate the students' active participation. The other eight criteria are considered "very good". Several suggestions are also presented such as the accuracy in writing the sentences so that it is much easily understandable.

The data of media evaluation aspect on this evaluation shows the average score 4.60 with a "very good" criterion, there are two good criteria on the aspect of the composition of the color and the presentation of every single slide. For the seven other criteria, the evaluation shows "very good".

\section{Data on Product Piloting from the Third Stage of Evaluation}

The third evaluation data were obtained through a small group evaluation. The evaluation was gathered from 15 students of VII and selected randomly with the criteria is that 5 students are from the high group, 5 students from the middle and the other 5 students from the middle group. Responses were given to each student separately. The data were then gathered or obtained through a questionnaire.

The data evaluation of learning aspect on the small group evaluation, consisting of 15 students, results in the average score of sixteen indicators that belong to a "very good" with the score 4.40 (5.00 scale) (very good). There are three indicators pertaining to a "good" criterion, and the rest have a "very good" indicator.

The aspect of material evaluation data on the small group evaluation shows the average score of 4.38 or "very good" (5.00 scale) (very good). Based on eleven reference indicators, there are two indicators belong to "good" and nine other indicators are "very good". The evaluation data on the material aspect of the small group evaluation functions as the reference to developing the media construction. The evaluation data on the material aspect of the small group evaluation shows 4.52 (very good), and the nine indicators marked as "very good".

\section{Data on Product Piloting from the Fourth Stage of Evaluation}

This fourth piloting data were obtained through a field trial. The trial was accomplished by 27 students of grade VII who were selected randomly. The criteria are that 7 students were from a high group, 10 students were from a middle group, and 10 students were from a lower group. They give their response separately. The one-to-one and small group evaluation consisted of 16 questions were reviewed based on the aspect of learning and 11 questions in accordance with 
TABLE I. EFFECTIVITY OF THE UTILIZATION OF ONLINE MODULE OF CIVIC EDUCATION

\begin{tabular}{|c|c|c|c|c|}
\hline No. & \multicolumn{2}{|c|}{ Note } & Average & Criteria \\
\hline \multirow[t]{4}{*}{1.} & \multicolumn{2}{|c|}{$\begin{array}{l}\text { Data on Product Piloting from } \\
\text { the First Stage of Evaluation }\end{array}$} & & \\
\hline & \multirow[t]{2}{*}{$\begin{array}{l}\text { Material } \\
\text { expert } \\
\text { evaluation } \\
\text { data }\end{array}$} & $\begin{array}{l}\text { Aspect } \\
\text { evaluation data } \\
\text { of learning by } \\
\text { the material } \\
\text { expert }\end{array}$ & 4,00 & Good \\
\hline & & $\begin{array}{l}\text { Aspect } \\
\text { evaluation data } \\
\text { of material by } \\
\text { material expert }\end{array}$ & 3,81 & Good \\
\hline & $\begin{array}{l}\text { Media } \\
\text { Evaluation } \\
\text { Expert Data }\end{array}$ & $\begin{array}{l}\text { Media aspect } \\
\text { evaluation data } \\
\text { by media } \\
\text { expert }\end{array}$ & 4 & Good \\
\hline \multirow[t]{4}{*}{2.} & \multicolumn{2}{|c|}{$\begin{array}{l}\text { Data on Product Piloting from } \\
\text { the Second Stage of Evaluation }\end{array}$} & & \\
\hline & \multirow[t]{3}{*}{$\begin{array}{l}\text { One to One } \\
\text { Evaluation }\end{array}$} & $\begin{array}{l}\text { The aspect of } \\
\text { Learning } \\
\text { Evaluation } \\
\text { Data }\end{array}$ & 4,40 & Very Good \\
\hline & & $\begin{array}{l}\text { The aspect of } \\
\text { Material } \\
\text { Evaluation } \\
\text { Data }\end{array}$ & 4,40 & Very Good \\
\hline & & $\begin{array}{l}\text { The aspect of } \\
\text { Media } \\
\text { Evaluation } \\
\text { Data }\end{array}$ & 4,60 & Very Good \\
\hline \multirow[t]{4}{*}{3.} & \multicolumn{2}{|c|}{$\begin{array}{l}\text { Data on Product Piloting from } \\
\text { the Third Stage of Evaluation }\end{array}$} & & \\
\hline & \multirow[t]{3}{*}{$\begin{array}{l}\text { Small Group } \\
\text { Evaluation }\end{array}$} & $\begin{array}{l}\text { The aspect of } \\
\text { Learning } \\
\text { Evaluation } \\
\text { Data }\end{array}$ & 4,40 & Very Good \\
\hline & & $\begin{array}{l}\text { The aspect of } \\
\text { Material } \\
\text { Evaluation } \\
\text { Data }\end{array}$ & 4,38 & Very Good \\
\hline & & $\begin{array}{l}\text { The aspect of } \\
\text { Media } \\
\text { Evaluation } \\
\text { Data }\end{array}$ & 4,52 & Very Good \\
\hline \multirow[t]{4}{*}{4.} & \multicolumn{2}{|c|}{$\begin{array}{l}\text { Data on Product Piloting from } \\
\text { the Fourth Stage of Evaluation }\end{array}$} & & \\
\hline & \multirow[t]{3}{*}{$\begin{array}{l}\text { Field } \\
\text { Evaluation }\end{array}$} & $\begin{array}{l}\text { The aspect of } \\
\text { Learning } \\
\text { Evaluation } \\
\text { Data }\end{array}$ & 3,96 & Good \\
\hline & & $\begin{array}{l}\text { The aspect of } \\
\text { Material } \\
\text { Evaluation } \\
\text { Data }\end{array}$ & 4,04 & Good \\
\hline & & $\begin{array}{l}\text { The aspect of } \\
\text { Media } \\
\text { Evaluation } \\
\text { Data }\end{array}$ & 4,11 & Good \\
\hline \multirow[t]{7}{*}{5 . } & \multicolumn{2}{|c|}{ Implementation stage } & & \\
\hline & \multirow[t]{3}{*}{$\begin{array}{l}\text { Experiment } \\
\text { class }\end{array}$} & Pre-test score & 68,5 & $\begin{array}{c}\text { Incomplete } \\
\text { yet }\end{array}$ \\
\hline & & Post-test score & 85 & Complete \\
\hline & & $\begin{array}{l}\text { Completeness } \\
\text { of learning }\end{array}$ & $92,30 \%$ & \\
\hline & \multirow[t]{3}{*}{ Control class } & Pre-test score & 68,11 & $\begin{array}{c}\text { Incomplete } \\
\text { yet }\end{array}$ \\
\hline & & Post-test score & 75,22 & complete \\
\hline & & $\begin{array}{l}\text { Completeness } \\
\text { of learning }\end{array}$ & $55,56 \%$ & \\
\hline
\end{tabular}

the material aspects, and 9 students were from the media aspect. The data show that the average score is on 3.96 (good), 16 trialed indicators are considered very good, 14 indicators are considered good.

On the aspect of material evaluation, it shows the score of 4.04 or "good" (5.00 scale) or "very good". Based on the eleven evaluated aspects/indicators, three indicators are considered "very good" and the eight other indicators are considered "good".

Based on the evaluation of field trial with 27 respondents, it depicts the result 4.11 or "good". The details are that of three indicators gain very good criterion i.e. on the indicator of text readability, font, and interaction with the students. The other six indicators are considered "good".

\section{E. Implementation Stage}

The module, after it was evaluated by the experts, one-to-one evaluated (accomplished by five students with their very cognitive competence), the small group evaluated by 15 subjects of research, field trialed with 27 students. Furthermore, the implementation stage was accomplished in class VII C on Wednesday, the teaching-learning process was attended by 26 students as the subject of the research.

The implementation stage in class VII C shows the increase of the learning outcome. Based on the average after using the online module in the experiment class, from 68.58 to 85.00 , or it enhances 16.423 points. Therefore, the statistical data based on the paired t-test in the score $\alpha 5 \%$, it results in the significant difference in the previous and aftermath of the use of online media $(\mathrm{p}<0.05)$. hence, it can be concluded that the experiment of the online module is considered effective. The exhaustiveness of the students learning is on $92.30 \%$ so that it can be reckoned that the use of the online module of the civic education for the junior high school was considered as effective.

The control class, on the implementation stage in class VII A, shows the cultivation of their learning outcome classically which is depicted from the average of their pre-test score of 68.11 and their posttest 75.22. Further, based on the result of the paired ttest, it shows that the difference between the score of the pre- and post-test is significant $\left(\mathrm{t}_{\text {score }}=3.899\right.$ with $\mathrm{p}<0.05)$. Henceforth, it can be concluded that the control group experiences the improvement of the meaningful test result. The completeness of the students learning is $55.56 \%$ so that it has not yet effective.

Departing from the learning outcome of those two classes (experiment and control class), it can be concluded that the use of the online module of civic education for junior high school students is considered effective. It is picturized from the result of the improvement of the students learning outcome. Indeed, most of the class is at $92.30 \%$. 
Statistically, the difference between those two groups can be proved based on their post-test. The result shows that $\mathrm{t}_{\text {score }}=4.564$, significant $(\mathrm{p}<0.05)$. Therefore, it can be concluded that those two groups have a significant difference between their post-test. Overall, the effectiveness of the use of the online module of the civic education is picturized as the following table.

\section{CONCLUSION}

The result of this study is an online module for civic education of junior high school students in order to enhance their learning outcomes, material of independence in expressing opinion is presented in a form of module which is able to be accessed through internet, feature in the development of online module is in the form of a learning containing application containing application instruction, module instruction, preface, first, second, and third learning materials, tasks, case study, learning video, bibliography, and profile of module developer. The eligibility of the online module is considered high. It is proved by (a) expert validation (materials and media), (b) one by one piloting, (c) small group piloting with a high average score, and (d) field piloting with criteria (good). The implementation of the online module for senior high school students is effective to cultivate their learning outcomes with the score of $92.30 \%$.

\section{REFERENCE}

[1] Borg R Walter \& Gall M.D. Educational research; An Introduction, 2003.

[2] Daryanto. Menyusun Modul bahan ajar untuk persiapan guru dalam mengajar. Yogjakarta: Gava Media.

[3] Direktorat Tenaga Kependidikan. Penulisan Modul. Jakarta: Depdiknas, 2008.

[4] Ishak Abdulhak \& Deni darmawan Teknologi Pendidikan. Bandung: PT. Remaja Rosdakarya, 2013.

[5] Parmin, Peniati. Pengembangan modul mata kuliah stateg belajar mengajar IPA berbasis hasil penelitian pembelajaran Semarang, 2012. http://journal.unnes.ac.id/index.php/jpii.

[6] Putranto, Hari. Pengembangan e-Modul Online Instalasi listrik, Pemasangan, dan keamanan instalasi pada Pendidikan jarak Jauh. Teknologi dan Kejuruan, vol. 36, No.1, February 2013, pp. 63-74.

[7] Sumaidi Pengaruh Perkembangan Teknologi di Kalangan Remaja, 2016. Diakses http://kompasiana.com

[8] Soemantri, Muhammad Nukman. Menggagas Pembaharuan Pendidikan IPS. Bandung: PT. Remaja Rosdakarya, 2001.

[9] Suwasono. Pengembangan e-Modul online Elektronika AnalogPada Pendidikan jarak Jauh. Teknologi dan Kejuruan, Vol 36, No.1, Februari 2013, pp. 51-62.

[10] UU RI. Undang-undang sistem pendidikan nasional. Surabaya: Kesindo Utama, 2009.

[11] Widiarni, Dyah Rahayu. Keberhasilan Belajar Mengajar, 2008.

[12] Wijanarka, Bernadus Sentot. Pengembangan Modul Dan Pembelajaran Kompetensi Kejuruan Teknik Pemesinan CNC SMK. Disertasidoktor, Universitas Negeri Yogyakarta, 2012. 